\title{
Analysis of Use of Global Distribution System In Tourism Industry In Indonesia Using Technology Acceptance Model: a pilot survey in Bali.
}

\author{
$1^{\text {st }}$ Nyoman Mastiani Nadra \\ Tourism Department, \\ Bali State Polytechnic \\ Denpasar-Bali, Indonesia \\ email : madebudiasa@pnb.ac.id
}

\author{
$2^{\text {nd }}$ I Gusti Agung Bagus Mataram \\ Tourism Department, \\ Bali State Polytechnic \\ Denpasar-Bali, Indonesia
}

\author{
$3^{\text {rd }}$ I Made Budiasa \\ Tourism Department, \\ Bali State Polytechnic \\ Denpasar-Bali, Indonesia
}

\begin{abstract}
Tourism advances are heavily influenced by advances in information and communications technology (ICT) on the operation, structure and business strategy of the tourism industry. The use or adoption of GDS (Global Distribution System) in the tourism industry, especially in travel agents, airlines and hotels can increase the availability, frequency and speed of communication among tourism businesses in providing services to potential customers. The purpose of this research is to know the result of concept / model test as a pilot study about predictors influencing the use of GDS in tourism business especially travel agents (BPW), airlines and hotels in Indonesia with analysis using TAM (Technology Acceptance Model) as the basis. The method used in this research is the method of survey on a rolling basis (snowball sampling) by using questionnaires to 200 respondents as samples derived from companies using GDS such as BPW, airlines, and hotels in Indonesia, especially in Bali and East Java. Data analysis was done quantitatively with the help of SPSS 17.0. Tests of the validity and reliability for the instrument, confirmatory factor analysis and multiple regression are performed. The theory used in this research is TAM (Technology Acceptance Model) as the basis and other theories complete the analysis. The variables used are Perceived Ease of Use, Perceived Usefulness, Awareness, Perceived Risk Communication Channels and Job Relevance as independent variables and Behavioral intention to use GDS (BI) as dependent variable. The result of this research show that Perceived Ease of Use, Perceived Usefulness, Awareness, and Communication Channels and Job Relevance were found significantly influence Behavioral intention to use GDS, whereas Perceived Risk were found not significantly influence Behavioral intention to use GDS.
\end{abstract}

Keywords- ICT adoption, Global Distribution System, Technology Acceptance Model, Tourism Industry

\section{A. INTRODUCTION}

Tourism advances are heavily influenced by the advances in information and communications technology (ICT) in terms of work, structure and business strategy in the tourism industry [3]. The use or adoption of GDS (Global Distribution System) in the tourism industry, especially in travel agents, airlines and hotels can increase the availability, frequency and speed of communication among companies in providing services to tourists.

The [34] or World Tourism Organization states in January 2016 a benchmark for the continued growth of international tourist arrivals between $3.5 \%$ and $4.5 \%$, in accordance with the Tourism Vision Going to 2030, the long-term growth projection is $3.8 \%$ year for the $2010-2020$ period.

International tourism in 2016 represents $7 \%$ of world exports of goods and services, up from 6\% in 2014, which means tourism has grown faster than world trade for the past four years.

The development of the tourism industry in Indonesia continues to increase is also accompanied by the development of the use or adoption of ICT (information and communication technology) that has been progressing from year to year. One use of ICT is the use of GDS (Global Distribution System) at BPW (travel agency), airlines, and hotels to communicate in serving tourists..

GDS is a system or software with internet connection used by BPW (travel agency), airline, and hotel to communicate in selling products. Through GDS, BPW (travel agency) and APW (retail travel agent) can sell flight ticket products, hotel rooms and rent-car (car rental), and insurance to potential tourists. In the sale of airline tickets, through GDS can be accessed various information such as schedule (flight schedule), availability (availability of seats), type and flight routes, departure time from the city of origin, transit time and place and arrival time and place at destination, specification of aircraft type, types of food available, and other special services in flight. Likewise with hotel products, rent-car and travel insurance. There are several kinds of GDS used by tourism industry in Indonesia especially BPW or travel agent, airlines and hotels such as Amadeus (1A), Saber (1S), Galileo International (1G), Wordspan (1P) and Apollo (1V).

According to the theory of TAM (Technology Acceptance Model) proposed by [11], there are several factors that influence the adoption / use of ICT (Information and 
Communication Technology), among others, the user perceptions of Perceived Usefulness and user perceptions of the ease of use (Perceived Ease of Use). Other factors are Perception of Understanding (Awareness) [12]; [35], Perceived Risk [27] and communication channels [29].

The purpose of this research is to examine the result of concept / model test as a pilot study on predictors influencing the use of GDS in tourism business especially travel agents (BPW), airlines and hotels in Indonesia especially in Bali at the moment with analysis using TAM (Technology Acceptance Model) as the basis.

\section{A. Literatue Review}

\section{a. The Constructs development}

The constructs in this research were developed from some related literature and modified for the context of GDS usage when needed. Perceived ease of use and perceived usefulness variables were taken from a number of sources [11]; [20]; [28]; [31]; [7]. Awareness variable from [30] \& [6]; [10] and [2], perceived risk variable were derived from other previous studies according to [36] and [31], and Communication Channels are adapted from [29]. Behavioural intention variable were taken from [33 ], [28] and [31] and Relative Advantage were taken from [26], [22]; [24].

\section{b. Global Distribution System (GDS)}

Global Distribution System is "A worldwide computerized reservation network used as a single point of access for reserving airline seats, hotel rooms, rental cars, and other travel related items by travel agents, online reservation sites, and large corporations. The premier global distribution systems are Amadeus, Galileo, Sabre, and Worldspan. They are owned and operated as joint ventures by major airlines, car rental companies, and hotel groups. It is also called automated reservation system (ARS) or computerized reservation system (CRS)" [15]. GDS is "The name for a computer (computerized) travel and tourism reservation system operating worldwide. GDSs provide a speedy, efficient, and secure means of access to travel and tourism information and booking via the Internet or a direct connection. Their services are provided for consumer end users, bricks and mortar travel agencies, and OTAs (Travel Management companies are merely a specialized type of travel agent)" [16].

\section{c. Perceived Ease of Use (PEU)}

According to [11] perceived ease of use is the extent to which a person believes that using a particular system will be free of effort. Perceived ease-of-use is a person's subjective perception of the effortlessness of a computer system, which affects the PU thus having an indirect effect on a user's technology acceptance [22]. The easier it is for a user to interact with a system, the more likely he or she will find it useful. There is substantial empirical support for this view [6], [17].

\section{d. Perceived usefulness (PU)}

Perceived usefulness is one of the components of Technology Acceptance Model (TAM), which has been widely used by information system researchers. According to [5]'PU is the extent to which a person believes that using a particular system will enhance his or her performance" [29]. [30] defined PU as the extent to which a person deems a particular system to boost his or her job performance. It is the primary prerequisite for mass market technology acceptance, which depends on consumers' expectations about how technology can improve and simplify their lives [3]. Empirical studies on TAM have suggested that PU has a positive effect on the adoption of information technology [32].

\section{e. Awareness $(A W)$}

According to [21] \& [4], awareness of service has direct influence on user intention to use the technology. Furthermore, behavioral intentions depend not only on personal characteristics, but also on the level of awareness as stated by [10] and [2].

\section{f. $\quad$ Perceived risk $(P R)$}

This construct reflects an individual's subjective belief about the possible negative consequences of some type of planned action, due to inherent uncertainty which is likely to negatively influence usage intentions. [36] and [31]

\section{g. Communication channels $(C C)$}

[29] stated that Communication Channels have a significant and high relationship and effect or influence on the actual use of internet as the form of technology. In case of the effect or influence on the actual use of technology, Communication Channels have contributed to the variations in actual usage of the technology.

\section{h. Relative Advantage (RA)}

Relative Advantage refers to the degree to which an innovation is perceived as being better than its precursor. [26] [22]; and [24].

\section{i. Behavioural intention (BI)}

[19] refer to the Theory of Reasoned Action (TRA), which is among the most popular belief models [1]. They stated that an individual's intention to perform or not to perform a given task is determined by their attitude towards behavior. Furthermore, behavioral intentions depend not only on personal characteristics, but also on the level of awareness as stated by [10] and [2].

\section{j. Preliminary studies}

Preliminary research on Factors that influencing the usage of global distribution system in the case of Bali was done by [8] in 2017, which were using only 80 samples. The number of factors used were only 5 factors. The findings was Perceived Ease of Use, Perceived Usefulness, Awareness, and Communication Channels were found significantly influence Behavioral intention to use GDS, whereas Perceived Risk were found not significantly influence Behavioral intention to use GDS. Therefore, this research was a further study in the form 
pilot survey in Bali on Factors that influencing the usage of global distribution system in Indonesia. This study using six factors i.e. Perceived Ease of Use, Perceived Usefulness, Awareness, Communication Channels and Relative Advantage.

\section{RESEARCH METHOD}

Based on the literature review above, research model and hypotheses can be formulated. The proposed research model is described below in Figure 1.

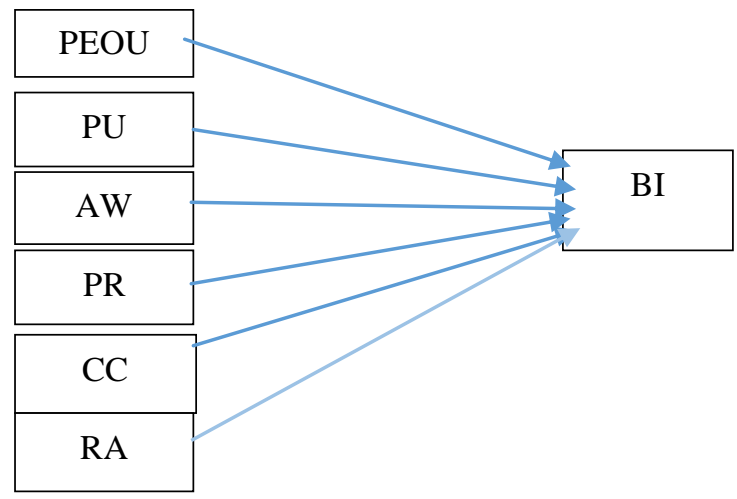

Fig.1. Proposed Research Model

Hypotheses for this research are formulated as follows:

H1: Perceived ease of use has a positive effect on behavioral intention to use GDS

H2: Perceived usefulness has a positive effect on behavioral intention to use GDS

H3: Awareness has a positive effect on behavioural intention to use GDS

H4: Perceived risk has a negative effect on behavioral intention to use GDS

H5: Communication channels has a positive effect on behavioural intention to use GDS

H6: Relative Advantage has a positive effect on behavioural intention to use GDS

The method used in this research is the a cross-sectional survey on a rolling basis (snowball sampling) by using questionnaires to 200 respondents as samples derived from companies using GDS such as BPW, airlines, and hotels especially in Bali. The questionnaire, as an informationgathering tool, is divided into two sections. The first part is about the demographic characteristics, including gender, age, and level of education, while the second part relates to the proposed model constructs of perceived ease of use, perceived usefulness, awareness, perceived risk and communication channels and behavioral intention. The questionnaire used 1 to 5 Likert Scales to study the respondents' behavior for these factors, where 1 indicates "strongly disagree" and 5 indicates "strongly agree"

Data analysis was done quantitatively with the help of SPSS 17.0. Tests of the validity and reliability for the instrument, factor analysis and multiple regression are performed. Pearson Correlation was used to test the relation amongst items to measure all variables, factor analysis was done to confirm the reliability of the construct. Descriptive analysis was conducted to describe the respondents 'profile, i.e. gender, age, and level of education; mean and standard deviation and regression tests were to examine the influence of the independent variables (PEU, PU; AW, PR, CC and RA) towards the dependent variable (BI).

\section{RESULT AND DISCUSSION}

\section{a. Respondents Profile}

In Table 1 it is stated that the sample size consists of 200 respondents from tourism industries i.e. travel agents, airlines and hotels in Bali: 45\% (90) of the respondents are men and $55 \%$ (110) are women. Most of respondents (80 or 40,0\%) are aged between 30 and 39 years; $70(35,0 \%)$ are between 20 and $29 ; 40(20,0 \%)$ are between 40 and 49 , and $10(05,0 \%)$ are in the age range 50 plus years. The majority $(58,5 \%)$ of respondents hold a Diploma until Strata 1; 38,5\% are high school or below; and $03,5 \%$ Master's degrees or higher education. The vast majority $89(44.5 \%)$ of respondents have been working for 5 - 10 years, $50(25.0 \%)$ of respondents have been working for $0-4$ years, $43(21.5 \%)$ of respondents have been working for 11-19 years, while $18(0.9 \%)$ of respondents have been working for 20 - up years.

Table 1: Respondents' profile

\begin{tabular}{|c|c|c|}
\hline Characteristics & Frequency & $\%$ \\
\hline \multicolumn{3}{|l|}{ Gender: } \\
\hline Male & 90 & 45,0 \\
\hline Age group: & \multirow{4}{*}{70} & \\
\hline $20-29$ & & 35,0 \\
\hline $30-39$ & & 40,0 \\
\hline $40-49$ & & 20.0 \\
\hline \multicolumn{3}{|l|}{ Education level: } \\
\hline High school or below & 77 & 38.5 \\
\hline Diploma - S1 & 117 & 58.5 \\
\hline \multicolumn{3}{|l|}{ Length of working: } \\
\hline $0-4$ years & 50 & 25,0 \\
\hline $5-10$ years & 89 & 44,5 \\
\hline $11-19$ years & 43 & 21,5 \\
\hline $\mathrm{N}=200$ & 200 & $100 \%$ \\
\hline
\end{tabular}

\section{b. Scale Reliability}

The result of SPSS (Statistic Package for Social Science) version 17.0 which is used to analyse the data to obtain 
descriptive statistics, and the reliability of the questionnaire was tested using Cronbach's alpha measurements. The reliability coefficients alpha of all variables range from 0.642 to 0.995 , we used the criteria of Cronbach's alpha for establishing the internal consistency reliability: Excellent (a>0.9), Good $(0.7<\mathrm{a}<0.9)$, Acceptable $(0.6<\mathrm{a}<0.7)$, Poor $(0.5<\mathrm{a}<0.6)$, Unacceptable $(\mathrm{a}<0.5)$ [17]; [13]; [25]; [14]. The following are described in table (2): BI (0.642); PEU (0.882); PU (0.995); AW (0.819), PR (0.982); CC (0.988); RA (0.768).

Table 2: Scale Reliability

\begin{tabular}{|l|c|c|}
\hline \multicolumn{1}{|c|}{ Construct name } & $\begin{array}{c}\text { Number of } \\
\text { items }\end{array}$ & $\begin{array}{c}\text { Cronbach's } \\
\text { alpha }\end{array}$ \\
\hline Behavioral intention to use GDS (BI) & 3 & 0.642 \\
\hline Perceived ease of use (PEOU) & 4 & 0.882 \\
\hline Perceived usefullness (PU) & 4 & 0.995 \\
\hline Awareness (AW) & 3 & 0.819 \\
\hline Perceived risk (PR) & 3 & 0.982 \\
\hline Communication channels (CC) & 3 & 0.988 \\
\hline Relative Advantage (RA) & 3 & 0.768 \\
\hline
\end{tabular}

\section{c. Correlation Analysis}

A compute variable was used, based on the average score of multi-items for the constructs in the framework, as each construct was measured by several items in the questionnaire. This will be used in further analysis, such as regression and correlation. Person $r$ correlation was run to determine the relationship between independent variables (PEU, PU, AW, $\mathrm{PR}, \mathrm{CC}$ and RA) and the dependent variable (BI). [9] suggests that the correlation coefficient value (r) range from 0.10 to 0.29 is considered weak, from 0.30 to 0.49 is medium, and from 0.50 to 1.0 is strong. Results show that there was a strong, positive correlation and statistically significant between Perceived ease of use $(\mathrm{r}=.524, \mathrm{n}=200, \mathrm{p}<0.00)$, Perceived usefulness $(\mathrm{r}=.594, \mathrm{n}=200, \mathrm{p}<0.00)$, and Relative Advantage (RA) ( $\mathrm{r}=.522, \mathrm{n}=200, \mathrm{p}<0.00)$ towards Behavioural Intention to use GDS; and a medium, positive correlation and significant statistically between Awareness ( $\mathrm{r}$ $=.479, \mathrm{n}=200, \mathrm{p}<0.00)$, Communication channel $(\mathrm{r}=.337$, $\mathrm{n}=200, \mathrm{p}<0.01$ ) and Behavioural Intention to use GDS), However, Perceived risk ( $\mathrm{r}=023, \mathrm{n}=200,418>0.05)$ was weakly correlated and statistically not significant to Behavioural intention to use GDS in tourism industries in Bali.

\section{d. Normality, Multicollinearity and Heteroskedastic}

The result of analysis shows that the Sig value $0.313>$ 0.05 means that data distribution is normal and it can be analysed further to multiple regression. The result also shows that all the Tolerance value $=p>0.01$ and VIF value $p<10$ means that data is free from multicollinearity and can be analysed further to multiple regression. The analysis result shows that all the Sig value $p>0.05$ means that data is free from heteroskedastic and it can be analysed further to multiple regression.

\section{e. Factor Analysis, Reliability and Multiple Regression}

In this research, factor analysis was used to assess construct validity and principal components extraction with varimax rotation was run on 20 items. The Kaiser-MeyerOlkin (KMO) value of 0.814 and significance of Bartlett's statistic Chi-Square $=1895.310(\mathrm{p}<0.001)$ confirm the suitability of the factor analysis for the data set.

The factor loading illustrate all 20 items are clustered into six factors: Factor 1 (PEU), Factor 2 (PU), Factor 3 (AW), Factor 4 (PR), Factor 5 (CC) and Factor 6 (RA). The Eigenvalue for each factor is greater than 1.0 (7.576, 3.234, $1.785,1.616$ and 2.163). The cumulative percentage of variance explained by the five factors is 93.9 per cent.

Multiple regression analysis is applied to examine the association between a single dependent variable and number of independent variables [23]. The results of multiple regression analysis show that PEU $(\mathrm{p}<0.05)$, PU $(\mathrm{p}<0.05)$, AW $(\mathrm{p}<0.05) \quad \mathrm{CC}(\mathrm{p}<0.05)$ and RA $(\mathrm{p}<0.05)$ all significantly affect the behavioural intention to use GDS. However, PR $(0.349>0.05)$ was found not to be significantly linked to the behavioural intention to use GDS in tourism industries in Bali.

The Beta $(\square)$ value indicates that the factors contributing most to the behavioural intention to use GDS are PU (54.6\%), RA (42.9\%), CC (39.6\%), PEOU (31.8\%), AW(25.4\%). However, PR $(-00.9 \%)$ indicates that it was found not to be significantly linked to the behavioural intention to use GDS in tourism industries in Bali.

Determiner value $\mathrm{R} 2=0.823$ indicates that the model explains 82.3 per cent of the variance in the behavioural intention towards the use of GDS tourism industries in Bali.

$\mathrm{F}=33.405$ (Sig 0.000) shows the overall significance of the model as $\mathrm{p}<0.05$ or in other words, all independent variables influence simultaneously behavioural intention the use of GDS in tourism industries in Bali. The reliability and multiple regression test result is shown in Table 3.

Table-3. The Key Findings: result of the Reliability Test and Regression Test

\begin{tabular}{|l|l|l|l|l|l|}
\hline \multicolumn{1}{|c|}{$\begin{array}{l}\text { Factor } \\
\text { Name }\end{array}$} & $\begin{array}{c}\text { Cronba } \\
\text { ch's }\end{array}$ & t-value & $\begin{array}{l}\text { Sig } \\
(\mathbf{p})\end{array}$ & Beta & hypothesis \\
\hline $\begin{array}{l}\text { Perceived ease of } \\
\text { use (PEOU) }\end{array}$ & 0.642 & 4.100 & 0.020 & 0.318 & Supported \\
\hline $\begin{array}{l}\text { Perceived } \\
\text { usefulness (PU) }\end{array}$ & 0.882 & 5.526 & 0.000 & 0.546 & Supported \\
\hline
\end{tabular}




\begin{tabular}{|c|c|c|c|c|c|}
\hline Awareness (AW) & 0.995 & 3.878 & 0.000 & 0.254 & Supported \\
\hline Perceived risk (PR) & 0.819 & -0.187 & 0.349 & -0.009 & $\begin{array}{l}\text { Not } \\
\text { supported }\end{array}$ \\
\hline $\begin{array}{l}\text { Communication } \\
\text { channels (CC) }\end{array}$ & 0.982 & 5.812 & 0.000 & 0.396 & Supported \\
\hline $\begin{array}{l}\text { Relative Advantag } \\
\text { (RA) }\end{array}$ & 0.988 & 5.407 & 0.000 & 0.429 & Supported \\
\hline \multicolumn{6}{|c|}{$\begin{array}{l}\text { Adj.R Square }=0.670 \\
\text { R Square }=0.823\end{array}$} \\
\hline
\end{tabular}

Based on all the result of the data analysis above, the research model could be revised. The revised research model is described below in Figure 2.

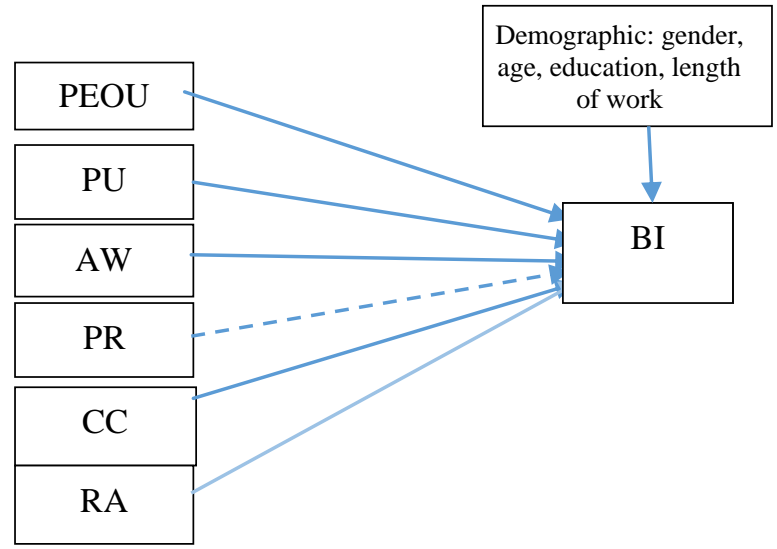

Fig. 2. Revised Research Model

From Figure-2 it can be explained that Perceived Ease of Use, Perceived Usefulness, Awareness, Communication Channels and Relative Advantage were significantly factors influence the Behavioural intention to use GDS, whereas Perceived Risk were found not significant influence the use of GDS.

Apart from data analysis result, it was found that most of airlines operated in Bali migrate from previous GDS system to Amadeus. Users stated the reasons that with the new GDS system it was more flexible and more complete features in the system.

\section{CONCLUSION}

The conclusion that could be drawn from this research is that this research describes the results of testing GDS acceptance in the tourism industry in Indonesia especially in Bali at the moment by appointing technology acceptance model as a base for this study integrated with other constructs such as awareness, perceived risk, and communication channel. This research found that Perceived Ease of Use, Perceived Usefulness, Awareness, Communication Channels and Relative Advantage were significantly influence the Behavioural intention to use GDS, whereas Perceived Risk were found not significant influence the use of GDS. The relatively small size of samples used in this research limits generalization for the outcome of the study. This study was conducted to explore the factors influencing the us of GDS in the tourism industries in Indonesia especially in Bali at the moment. Therefore, there is still chance for further research into the adoption of GDS usage in the tourism industries in a different area and different time periods that would provide more insight into the phenomenon of use of the GDS.

\section{ACKNOWLEDGMENT}

The author would like to thank Directorate of Research and Public Services Directorate General of Research Empowerment and Development Ministry of Research, Technological and Higher Education of the Republic of Indonesian and Bali State Polytechnic for all the support.

\section{REFERENCES}

[1] [1]n I., (1991), The theory of planned behavior, Organizational Behavior and Human Decision Processes, 50, 179-211.

[2] Akman I., Yazici A., Mishra A., Arifoglu A., (2005), e-Gov: a global perspective and an empirical assessment of citizens' attributes, Government Information Quarterly, 22, 239-257.

[3] Algethmi, M. and De Coster, R. (2012). Factors affecting consumer acceptance of mobile services in the airline sector : the case of Saudi Arabia, International Journal of Management and Marketing Academy, Vol. 1, No. 1, pp. 32-49.

[4] Al-maghrabi, T \& Dennis, C., "Driving online shopping: Spending and behavioral differences among women in Saudi Arabia," International Journal of Business Science and Applied Management, vol. 5, no. 1, pp. 30-47, 2010.

[5] Alsajjan, B \& Dennis, C., "Internet Banking Acceptance Model: Cross-Market Examination,” Journal of Business Research. 2009.

[6] Al-Somali, S, Gholami, R \& Clegg, B., "An Investigation into the Acceptance of Online Banking in Saudi Arabia," Technovation, vol. 29 pp. 130-141, 2009

[7] Amin, H., "An Analysis of Online Banking Usage Intentions: An Extension of the Technology Acceptance Model," International Journal of Business and Society, vol. 10, no. 1, pp. 27-40, 2009.

[8] Budiasa, I M., Suparta, I K., \& Nadra, N. M. (2018). Factors that influencing the usage of global distribution system. Journal of Physics: Conference Series vol. 953, 6 February 2018.

[9] Cohen, J.W. (1988) Statistical power analysis for the behavior science.(2nd edn). Hillsdale, NJ: Lawrence Erlbaum Associates

[10] Cronan T.P., Leonard L.N.K., Kreie J., (2005), An empirical validation of perceived importance and behavior intention in IT ethics, Journal of Business Ethics, 56, 231-238

[11] Davis, F. D. (1989). Perceived usefulness, perceived ease of use, and user acceptance of information technology. MIS Quarterly, 13(3), 319 340 .

[12] Dwitama, F. (2014). Faktor-Faktor Yang Mempengaruhi Minat Nasabah Menggunakan Internet Banking Dengan Menggunakan Technology Acceptance Model (TAM) Pada Bank Mandiri. Diakses dar http://ejournal.gunadarma.ac.id/index.php/infokom/article/view/1099/96 0 
[13] George, D., \& Mallery, P. (2003). SPSS for Windows step by step: A simple guide and reference 11.0 update (4 th ed.). Boston: Allyn \& Bacon.

[14] Ghozali, Imam. 2012. "Aplikasi Analisis Multivariate dengan Program SPSS", Semarang: Badan Penerbit Universitas Diponegoro.

[15] http://www.businessdictionary.com/definition/Global-DistributionSystem-GDS.html.

[16] http://www.oxfordreference.com

[17] Kline, p. (2000). The handbook of psychological testing (2 ed.). pp.13. London: Routledge.

[18] Lee, M., "Factors Influencing the Adoption of Internet Banking: An Integration of TAM and TPB with Perceived Risk and Perceived Benefit," Electronic Commerce Research and Applications, vol. 8, pp. 130-141, 2009.

[19] Mallat, N., Rossi, M., and Tuunainen, V. K., Öörni, A. (2006) The Impact of Use Situation and Mobility on the Acceptance of Mobile Ticketing Services. In Proceedings of the 39th Hawaii International Conference on System Sciences, Hawaii.

[20] Mathwick, C, Rigdon \& Malhotra, N., "The Effect of Dynamic Retail Experiences on Experiential Perceptions of Value:an Internet and Catalog Comparison," Journal of Retailing, vol. 78, no. 1, pp. 51-60., 2001.

[21] Mishra, Alok and Akman, Ibrahim. (2014). Green Information Technology (Git) And Gender Diversity. Environmental Engineering and Management Journal, December 2014, Vol.13, No. 12, 2999-3007.

[22] Moore, G.C., and I. Benbasat (1991) "Development of an Instrument to Measure the Perceptions of Adopting an Information Technology Innovation" Information Systems Research 2(3), pp.192-222.

[23] Pallant J. SPSS Survival Manual: A Step by Step Guide to Data Analysis using SPSS for Windows. (4th edition, Open University Press, 2010).

[24] Premkumar, G., and M. Potter (1995) “Adoption of Computer Aided Software Engineering (CASE).Technology: An Innovation Adoption Perspective" Data Base 26 (2\&3), pp. 105-124.

[25] Rigopoulos, G \& Askounis, D., "A TAM Framework to Evaluate Users' Perception towards Online Electronic Payments," Journal of Internet Banking and Commerce, vol. 12, no. 3. 2007.
[26] Rogers, E.M. (1983) Diffusion of Innovations New York, NY: The Free Press.

[27] Safeena, Rahmath. (2010) Customer Perspectives on E-business Value: Case Study on Internet Banking. Journal of Internet Banking and Commerce, April 2010, vol. 15, no.1

[28] Sakulsureeyadej, Apichai. How technology is changing global tourism, World Tourism Organization (UNWTO) Affiliate Members AMreports-Technology in Tourism (Vol. 1, 2011).

[29] Salman, A., Abdullah, M. Y. H., Aziz, J., Ahmad, A. L., \& Kee, C. P. (2014). Remodelling Technology Acceptance Model (Tam) In Explaining User Acceptance Towards Information And Communication Technology. International Journal of Arts \& Sciences, 7(1), 159-171.

[30] Sathye, M. Adoption of Internet Banking by Australian consumer: an empirical investigation. International Journal of Bank Marketing 17(7), 2009, pp. 324-334.

[31] Sweeney, J. C., G. N. Soutar, and L. W. Johnson, "The Role of Perceived Risk in the Quality-Value Relationship: A Study in A Retal Environment", Journal of Retailing, Vol. 75, No. 1: 77-93, 1999.

[32] Taylor, S. and Todd, P. (1995) Assessing IT usage: the role of prior experience .MIS Quarterly, Vol. 19 No. 4, pp. 561-70

[33] Thompson, R. L., Higgins, C. A., and Howell, J. M. "Influence of Experience on Personal Computer Utilization: Testing a Conceptual Model," Journal of Management Information Systems (11:1), 1994, pp. 167-187

[34] UNWTO. (2017). UNWTO World Tourism Barometer, Volume 15, June

2017 http://cf.cdn.unwto.org/sites/all/files/pdf/unwto_barom17_03_june_exce rpt_1.pdf

[35] Wadie, N., \& Allagui, A. (2013).Expanding the Technology Acceptance Model to Examine Internet Banking Adoption in Tunisia Country. International Journal of Innovation in the Digital Economy, 4(4), 61-81, October-December 2013.

[36] Zhang, X., and Prybutok, V.R. 2005. A consumer perspective of eservice quality. IEEE Transactions on Engineering Management, Vol. 52, no.4: 461-477 University Science, 1989. 